Textos 



\title{
Cinco teses sobre a relação da religião com a política
}

\author{
ROBERTO MANGABEIRA UNGER
}

\author{
A tese da personalidade
}

$\mathrm{U}$

MA EXPERIÊNCIA EXEMPLAR de possibilidades de ligação pessoal de relacionamentos intensos e transformadores entre os indivíduos - constitui parte central das visões desenvolvidas pelas históricas religiões da salvação. Cada uma dessas visões promete a felicidade mediante a anulação ou atenuação do conflito entre a necessidade que temos uns dos outros e o risco que criamos uns para os outros. Experimentar de algum modo essa reconciliação é tornar-se livre; prometer a felicidade é prometer a liberdade. A estrutura narrativa da crença das religiões históricas apresenta um mundo em que a promessa de felicidade faz sentido. O imperativo ético das religiões históricas mostra como este mundo pode ser transformado em realidade, reforçando seu poder de alavancagem na vida de cada dia.

Essa interpretação das religiões certamente privilegia as formas de consciência religiosa que colocam o pessoal acima do impessoal (por exemplo, a religião da Bíblia acima das doutrinas de Platão ou Spinoza). Pode, porém, abarcar até mesmo aquelas, como o Budismo, que rejeitam a realidade da experiência individual em toda a sua extensão, pois o que a estrutura narrativa dessas religiões parece negar, seu imperativo ético pode reafirmar. Além disso, esse modo de entender a religião também sugere um modo de evitar a escolha entre explicações metafóricas e explicações literais da crença religiosa.

A relação básica da religião com a política decorre do papel formador atribuído às relações pessoais exemplares da experiência e visão religiosas. A forma mais significativa de teologia política não está no ensino oficial sobre o Estado, mas na imagem de possíveis associações humanas que se representa na comunidade e nas ações dos crentes. Por exemplo, no Brasil os movimentos pentecostais, promovendo conversões aos milhões, oferecem um liberalismo prático - comunidades de eleitos, marcadas pelas qualidades de autoconfiança, confiabilidade, autoformação e respeito mútuo que faltam num mundo de patrões e clientes onde se confundem o poder, 
a permuta e o sentimento. Em contraste com isso, a Igreja Católica tradicional promete progresso por meio da resistência e do confronto proféticos e por meio do engajamento em associações secundárias mantendo uma relação de oposição aos poderes estabelecidos do governo, do capital e da televisão.

\section{A tese da democracia}

Os ideais políticos e morais de uma cultura muitas vezes equivaleram a uma transação entre a visão de relações pessoais exemplares expressas por uma religião influente e as preocupações das classes dominantes. Assim, as concepções burguesas do século XIX sobre a felicidade conjugal construíram uma ponte precária entre as esperanças cristãs e as realidades vitorianas. Todavia, a conexão entre o projeto democrático e a religião da Bíblia é mais íntima e interiorizada do que essa história de equívocos e atenuações poderia nos levar a esperar. A natureza dessa ligação é melhor esclarecida primeiramente pela investigação da relação problemática entre dois temas principais da religião da Bíblia: a idéia de espírito como o infinito preso no finito, como transcendência extrapolando o contexto, e a organização da experiência moral em torno do amor em vez do altruísmo.

Qual é a conexão entre esses dois temas? Segundo Hegel, o amor é a relação na qual mais plenamente reconhecemos e aceitamos uns aos outros como espíritos, isto é, como seres cujos poderes de insight, associação, transformação e autotransformação ultrapassam todos os mundos discursivos e práticos que nós criamos e nos quais vivemos.

O problema dessa fórmula hegeliana é que ainda não atingimos a plenitude desses seres que vão além de seu contexto; neles precisamos nos transformar. Um modo pelo qual o fazemos consiste na promoção do projeto democrático, concebido de modo a incluir a liberação progressiva de atividades e relacionamentos em relação à grade contextual da hierarquia e divisão social estabelecidas. O elemento religioso do projeto democrático é a busca de disposições sociais que nos disponibilizam mais plenamente uns aos outros como indivíduos que transcendem seu contexto, conforme a religião da Bíblia proclama que somos. O ponto fraco, porém, é a incapacidade de traduzir essa conexão declarada entre a visão religiosa e o progresso democrático numa concepção institucional promissora.

As conseqüências dessa incapacidade no Brasil tornam-se patentes nas transações entre a religião e a política. Três teologias políticas estão disponíveis no país. 
A primeira delas é o resíduo do ensinamento social tradicional da Igreja Católica. O comunitarismo corporativo do período entre-guerras do Quadragesimo Anno, com seu projeto de uma terceira via entre o capitalismo e o comunismo, perdeu seu atrativo, primeiro, por causa de sua proximidade do corporativismo fascista e, segundo, em nível mais profundo, por sua dependência sem garantias das instituições econômicas estabelecidas - corporações e sindicatos de trabalhadores e empregados concebidas como um modelo adequado para o comunitarismo de sua proposta. Essa doutrina neofeudal foi seguida por uma demanda de solidariedade social cada vez mais desprovida de conteúdo institucional, com exceção do conteúdo fornecido pelos conhecidos programas de imposto-transferência da democracia social contemporânea e pelas reivindicações de direitos sociais, sem o apoio de propostas de instituições econômicas capazes de garantir o gozo efetivo de tais direitos.

A segunda teologia política é a tentativa, típica dos movimentos pentecostais, de isolar-se num mundo purificado de aperfeiçoamento pessoal e respeito mútuo, exigindo do Estado concessões ocasionais ao mesmo tempo em que se aceita a sua estrutura concreta. Mas o grande mundo, que não é desafiado nem alterado, reage contra os pequenos mundos dos potenciais isolacionistas em busca do aperfeiçoamento pessoal, impondo restrições externas ao seu desenvolvimento e detendo, nas correntes do controle externo e da submissão interna, a dinâmica das relações pessoais exemplares.

A terceira teologia política é a da libertação da Igreja radical. Seu instrumento político é a parceira de facto entre a Igreja e o PT (Partido dos Trabalhadores). Diversamente das outras duas teologias políticas, esta positivamente renuncia ao conservadorismo tradicional e enfrenta o poder estabelecido. Todavia, essa atitude não vem acompanhada de qualquer proposta concreta de alternativas institucionais na organização do Estado, da economia, da sociedade civil e da família. O comprometimento com uma prática - organização de base e organização independente - preenche a lacuna deixada pela ausência de uma visão reconstrutiva. Decorre dessa deficiência uma divergência crescente entre a intenção transformadora ou profética e o conteúdo redistributivo ou aperfeiçoador das campanhas sociais em que se engaja a Igreja radical. O ativismo de base degenera em nova forma de orientação em que o padre ou partidário ativistas substituem o patrão. Assim, o vazio institucional da terceira teologia política acaba complementando em vez de contradizer o conservadorismo institucional das outras duas teologias políticas. 


\section{A tese macro-micro}

Tocqueville observou que a Revolução Francesa foi momentosa porque combinou uma revolução política com uma religiosa. O núcleo racional no arcabouço místico da idéia de revolução política é, nos dias de hoje, a macropolítica da mudança institucional; na idéia de revolução religiosa, o núcleo racional é a micropolítica da mudança nos estilos dominantes de relacionamento e expressão pessoais. O que essa tradução exclui do lado religioso é o elemento de crença urgente e praticada, dando sentido ao imperativo da mudança e enraizando-o numa visão mais ampla de solidariedade e possibilidades humanas.

A ligação estimulante entre a macro e a micropolítica, embora seja convencionalmente reconhecida como indispensável, é um fato raramente assegurado. Onde uma dessas formas de política se torna a mais forte, a outra muitas vezes permanece a mais fraca. Em conseqüência, programas de mudança institucional têm geralmente seus efeitos pervertidos ou revertidos pelo estilo de associação pessoal que não conseguiram mudar. Dissociada de esperanças de reconstrução social, a política cultural-revolucionária de relações pessoais volta-se para dentro na direção do experimentalismo e narcisismo privados.

Uma consciência religiosa, quando se liberta do defeito espiritual do abandono do mundo e do defeito político do fetichismo institucional, consegue resistir a essa separação entre o macro e o micropolítico. Seu principal trabalho político é o de fazer a imaginação institucional lembrar-se das recalcitrantes realidades da necessidade pessoal - especialmente da necessidade que as pessoas têm umas das outras - ao mesmo tempo em que desafia a perversão narcisista do experimentalismo e emancipação individuais. Para realizar esse trabalho, porém, a consciência religiosa exige a compreensão das possibilidades sociais e institucionais. Mas não há lugar algum na alta cultura contemporânea onde ela possa ser instruída sobre isso com segurança. Ela precisa compensar de algum modo as conseqüência dessa lacuna intelectual desenvolvendo práticas alternativas de imaginação institucional.

No Brasil, como em grande parte do mundo, a ponte entre a macro e a micropolítica ainda não foi construída, em parte porque a religião não conseguiu construí-la. A teologia política dos pentecostais enfoca um mundo micro alheio ao mundo macro que ela não conseguiu desafiar ou mudar. A teologia política da Igreja Católica radical reduz o problema de reformar os mundos macro e micro à promoção de uma prática de engajamento e resistência. A teologia política da Igreja tradicional tem-se inclinado para a panacéia de democracia social de imposto-transferência, depois de perder a 
confiança na fórmula do comunitarismo corporativo. Todas as três teologias políticas estão agora institucionalmente vazias. Seu vazio institucional enfraquece-lhes a força profética e desorienta a visão política.

\section{A tese do antiparticularismo}

Uma experiência religiosa fundada na dinâmica personalista da transcendência e do amor acaba subvertendo os privilégios e as exclusões étnicas, nacionais, culturais e de gênero, mesmo quando parece atribuir a essas distinções significados e valores religiosos. Esse potencial subversivo tem na experiência religiosa duas de suas raízes principais - pelo menos na experiência da religião da Bíblia. A primeira raiz é o esforço de basear nossa ação no discernimento de que nossa capacidade pessoal individual supera os mundos práticos e discursivos particulares por nós construídos e habitados. Podemos desenvolver disposições que respeitam e moderam essa desproporção. A segunda raiz é o impulso de nos tornarmos disponíveis uns aos outros de modo prático e apaixonado como indivíduos e não como ocupantes de um lugar nas divisões e hierarquias sócio-culturais.

As religiões históricas parecem diferir em sua avaliação explícita do significado e finalidade de distinções nacionais: Cristianismo e Budismo de um lado; Hinduísmo e Judaísmo de outro; e uma ampla gama de religiões (africanas e japonesas, por exemplo) na posição intermediária. Todavia, mesmo nas religiões supostamente sectaristas e excludentes, ao mistério da eleição e distinção nacionais (como fatos relacionados à nossa natureza incorporada e localizada) a profecia contrapõe o mistério de nosso poder de agir com base no conhecimento de que as divisões no seio da humanidade pertencem ao enredo mais do que à mensagem e no fim devem ser desafiadas.

A privatização das religiões nas sociedades democráticas liberais contemporâneas abafa esse impulso subversivo e universalizante obrigando-o a falar no mundo público uma linguagem puramente secular de direitos e conscientização. As asserções religiosas mais ferozes do particularismo ficam assim esvaziadas de inimigos religiosos. Mais ainda, o vazio institucional das teologias políticas dominantes torna essas teologias impotentes para resistir ao que está se tornando a forma dominante de chauvinismo grupal no mundo contemporâneo: a afirmação de uma vontade abstrata de diferença coletiva, que está ficando cada vez mais intensa à medida que diferenças de costume e sensibilidade vão perdendo sua força.

Um povo luta para separar-se de seus vizinhos não porque tenha um modo de vida a resguardar, mas porque esse modo de vida lhe falta e ele 
quer tê-lo ou quer pensar que já o tem. Dois povos que tenham obtido maior êxito na sustentação de uma autonomia prática são os mais implacáveis saqueadores de práticas e instituições do mundo, em sua busca oportunista do que funciona melhor. A incapacidade de desenvolver ou sustentar diferenças reais torna a afirmação dessas diferenças imaginadas ou desejadas muito mais implacável: identidades abstratas, diferentemente de disposições concretas, situam-se além da possibilidade de acordos ou novas combinações, e a impotência causa a raiva.

Quanto mais plena e livremente a religião se envolve com a política tanto maior será a probabilidade de ela entrar nessa guerra combatendo unicamente a favor do lado sectarista. Quanto mais uma teologia política se equipar de imaginação institucional tanto maior será sua capacidade de desenvolver formas diferentes de vida e reforçar, com essa experiência de poder coletivo, a magnanimidade dos autoconfiantes.

A vida religiosa do povo brasileiro permite-nos ver essas circunstâncias ainda de outra perspectiva. A ausência de uma verdadeira luta dentro e fora da religião entre tendências universalizantes e sectaristas ajuda a maioria dos brasileiros a manter baixo o nível da energia religiosa. Tanto a religiosidade católica tradicional como seu rival pentecostal participam da vida social de um modo que não é nem político nem estritamente privatizado mas sim doméstico: um conjunto de práticas rituais, meias crenças e fragmentos de práticas corriqueiras, que reforçam a vida em família e suavizam o desespero de cada dia. O que os rituais e crenças católicos fazem pelas classes médias assalariadas, sua contrapartida pentecostal vem fazendo, cada vez mais, pela massa de trabalhadores que tentam se erguer e atingir a condição de autoconfiança e melhoria pessoal. Religião de baixa energia continua sendo a norma. Essa desmobilização religiosa, ofuscada pelos conflitos religiosos mais notórios, enfatizada nas teologias políticas atuantes, é ao mesmo tempo a causa e a conseqüência da supressão de problemas de raça e gênero.

\section{Tese do agente perdido}

À medida em que o conteúdo da crença religiosa muda, também devem mudar os agentes da ação religiosa. Quem são os agentes de uma prática de religião que tem seu centro na experiência pessoal exemplar, que reconhece a relação da fé com a democracia, que conecta o grande mundo das instituições com o pequeno mundo das relações pessoais mediante uma prática e visão de reconstrução social e que deixa livre a força que subverte o particularismo de suas sugestões proféticas? 
A história moderna da religião assistiu à difusão da idéia do sacerdócio de todos os crentes. Mas há dois problemas: o primeiro, é que a religião descrita nas primeiras quatro teses exige que todos os crentes sejam profetas além de sacerdotes; o segundo problema é que a experiência característica de viver na fé tornou-se hoje uma experiência em que as mesmas pessoas são simultaneamente crentes e não-crentes. Nem a igreja, nem o partido político, nem a parceria entre essas duas entidades pode se expressar adequadamente em nome dessa religião e dessa experiência. Quem então pode fazê-lo?

O perigo moral e psicológico é o de que essa religião possa proporcionar o veículo e a oportunidade a uma liderança carismática - não apenas na política entendida de modo estrito, mas em cada cenário da vida social. Os seguidores dos líderes carismáticos, como os trabalhadores mobilizados pelos ativistas proféticos da Igreja Católica radical no Brasil, sentem-se então dilacerados entre a sensação de estarem inspirados e a de estarem excluídos do poder e da graça da inspiração original. O antídoto é conectar o grande mundo das instituições e o pequeno mundo das relações pessoais de maneiras que permitam que as pessoas participem dos conflitos de visão e que as lembrem de seu poder de resistir, transcender e conectar-se, diminuindo a dependência da atuação privilegiada da liderança carismática. Para tanto, precisamos de instituições políticas e econômicas, e de estilos de associação pessoal que acelerem o experimentalismo em cada domínio da vida social. Desse modo damos um significado prático à idéia de transformar todos em profetas.

Roberto Mangabeira Unger é professor titular de Direito da Universidade Havard (EUA). Foi professor-visitante do Instituto de Estudos Avançados da USP em 1998.

Tradução de Almiro Pisetta. O original em inglês - Five theses on the relation of religion to politics, illustrated by allusions to Brazilian experience - encontra-se à disposição do leitor no IEA-USP para eventual consulta. 